\title{
IMAGES OF POLITICAL LEADERS OF ADVANCED FOREIGN COUNTRIES IN THE MINDS OF RUSSIAN CITIZENS: GENERAL ANALYSIS OF PROBLEMATICS
}

\section{Yuri M. Brumshteyn (a)}

(a) Astrakhan State University. Astrakhan, Russia. Email: noname@noname.ru

\begin{abstract}
The importance of solving the problem of evaluation and management of foreign politicians' images is justified. The content of the "image of the political leader of the advanced foreign country (PLAFC) in the minds of Russian citizens (RCs) concept is reviewed. The main "components" of these images, their formation peculiarities and RCs' perception in information and telecommunication technologies development are described.
\end{abstract}

Purposes and methods (technologies) of PLAFCs' image-building management in the RCs' minds, ensuring the stability of these images over time; "promotion" of information on the PLAFCs in infosphere; ensuring its visibility and accessibility for RCs, including World Wide Web, are studied from the positions of interest of various groups of an individual person and legal entity (Russian and foreign).

Taking into account developing opportunities and the volume of usage of information and telecommunication technologies, the following issues were analyzed: change in the structure and characteristics of information about PLAFCs incoming to the RCs of fact; selection and usage of methods for controlling the composition and volume of incoming information.

It is testified that in RCs' minds the images of PLAFCs are for medwith thematic composition, content, tonality and volume of information about the PLAFCs previously accumulated and newly received; by information evaluation approaches of different categories of RCs, by their age, social and economic group, level and scope of education and some other factors.

\section{Keywords}

foreign countries; political leaders; images of leaders; perception of images; Russian citizens; component structure of images; information and telecommunication technologies; World Wide Web; information assets; information channels; data streams; information evaluation

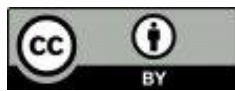

This work is licensed under a Creative Commons «Attribution»4.0 International License 


\section{ОБРАЗЫ ПОЛИТИЧЕСКИХ ЛИДЕРОВ ВЕДУЩИХ ЗАРУБЕЖНЫХ СТРАН В СОЗНАНИИ РОССИЙСКИХ ГРАЖДАН: ОБЩИЙ АНАЛИЗ ПРОБЛЕМАТИКИ}

\section{Брумштейн Юрий Моисеевич (а)}

(a) Астраханский государственный университет. Россия, Астрахань. Email: noname@noname.ru

\section{Аннотация}

Обоснована важность решения задач оценки и управления образами зарубежных политиков для достижения различных целей. Рассмотрено содержание понятия «образ политического лидера (ПЛ) ведущей зарубежной страны (ВЗС) в сознании российских граждан (РГ)». Охарактеризованы основные «компоненты» этих образов, особенности их формирования и восприятия РГ в условиях развития информационно-телекоммуникационных технологий.

С позиций интересов различных групп юридических и физических лиц (российских и зарубежных) исследованы цели и методы (технологии) управления формированием образов ПЛ ВЗС в сознании РГ; обеспечения устойчивости этих образов во времени; «продвижения» информации о ПЛ ВЗС в информационном пространстве; обеспечения ее известности и доступности для РГ, в т.ч. в Интернетпространстве.

С учетом развития возможностей и объемов использования информационнотелекоммуникационных технологий проанализированы следующие вопросы: изменение структуры и характеристик информации о ПЛВЗС, фактически поступающей к РГ; выбор и использование ими методов управления составом и объемами поступающей информации.

Показано, что в сознании РГ образы ПЛ ВЗС формируются с учетом тематического состава, содержания, тональности и объемов информации о ПЛВЗС - ранее накопленной и вновь поступающей; подходами различных категорий РГ к оценкам этой информации с учетом их возраста, принадлежности к определенной социально-экономической группе, уровня и профиля образования, некоторых иных факторов.

\section{Ключевые слова}

зарубежные страны; политические лидеры; образы лидеров; восприятие образов; российские граждане; компонентная структура образов; информационнотелекоммуникационные технологии; Интернет-пространство; информационные ресурсы; информационные каналы; потоки информации; оценки информации

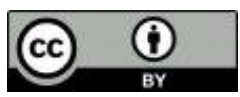

Это произведение доступно по лицензии Creative Commons «Attribution» («Атрибуция») 4.0 Всемирная 


\section{INTRODUCTION}

The rapid development of information and telecommunications technologies (ITCT) has significantly changed most Russian and foreign politicians' business environment; conditions and results of their images perceptions by individual persons (IP) of different ages and social and economic groups. It has also changed the amount of information potentially and actually available to them; their approaches to assessing the validity of this information. At the same time, the images of political leaders (PLs) of advanced foreign countries (AFCs) in the minds of various categories of Russian citizens (RCs) significantly affect the perception or evaluation of PLs' decisions or actions. They affect prediction of possible actions of PL AFCs; assessment and/or support for Russian politicians' actions in relation to these PLs under various conditions. However, inexistent Russian-language literature, the issue of evaluation and management of the PL AFCs images in the minds of citizens of our country are not fully studied. Thus, the objective of this article is attempting to recover. Forth, in default, we consider only PLs representing individual AFCs, not coalitions or international organizations

\section{THE IMAGE OF THE "POLITICAL LEADER OF AN ADVANCED FOREIGN COUNTRY" AND THE MAIN FEATURES OF ITS FORMATION IN THE MINDS OF RUSSIAN CITIZENS.}

We will include foreign countries from G20, that is, 19 countries. Now these particular countries play a key role in the development of the world economy, information and telecommunication technologies; formation of the World Wide Web.

By the term "political leader" of the AFCs we understand the IP who plays a major role in the political life of the state. Their positions in different countries can be called differently: the Prime Minister, Chairman of the Council of Ministers, Chancellor, President, etc. Forth, we believe that there may be only one PL for one country at a given point in time, however over time leaders may change.

Possible options for classification of foreign PLs are by role of these countries in the world economy; by population; by the nature of PLs' internal and foreign policy; PLs' personal political activity; on their informational activity on television, in the World Wide Web, etc. They are also classified by total duration of PLs' political activity; by sex and age. For the topic of this article, we will distinguish three categories of PLs, reserving that the boundaries between categories are "imprecise", they can 
change over time. (C1) National PLs, who are widely known in the international arena;(C2)PLs, who are well known and influential at the level of their "countries as a whole," but relatively little known outside them;(C3)PLs, who are known mainly in parts of "their" countries, politicians of a "regional" level.

The main types of the information involved in the formation of PL AFCs' images: text materials; static images (Svitich, 2019); combinations of images and texts; audio and audio-visual materials; hyperlinks to various objects - including text lines and icons. At the same time, printed publications, fragments of television and Internet broadcasting materials usually have electronic copies posted on the Internet.

In the minds of most citizens of our country, the "images" (Markelov, Brumshteyn \& Golovin, 2018), which can refer to different dates, as well as images of their countries, are usually associated mainly with the PLs' surnames. However, generally, the "image" (Vasilevoy, 2016; Karimova, 2012; Kurkemova, 2018) of the PL AFCs in the minds of RCs may consist of a wider set of "components." (a) Factual information about the PL AFCs on their "web pages" of the state authority of the country; (b) data on PL AFCs on Wikipedia - primarily in Russian one; (c) "accounts" of PL AFCs in "social networks"; (d) information on the types (methods) of political activity of certain PLs in solving various internal and foreign policy tasks, including the degree of its rigidity, coherence in implementation, rationality of strategic decisions; (e) speed and adequacy of PLs' rapid responses to changes in internal and external situations: political, economic, military, informational, biomedical, demographic, environmental, etc.; (f) PLs' interaction organization with various categories of legal entities and/or individual persons, including foreign politicians and their associations; leaders of political parties and social movements of "their own" country; the media in general; business elites of "their" and other countries; journalists; political scientists, cultural figures (especially popular artists), scientists, educational workers, healthcare workers, sportsmen, religious figures; children, etc.; (g) a set of "personal characteristics" of PL AFCs, including the following: gender, age, typical appearance in photographs and videos; anthropometric indicators; presence/absence of signs of certain types of diseases; a general manner of behavior; gestures, (Saprykina, 2018) facial expressions, speech; information about their family lives, relatives, closest friends. At the same time, the "gender" of a PL now having the influence on the perception (Sineokaya, 2017), is no longer a key factor; (h) peculiarities of hairdos, clothes (including clothes according to multinational and national norms), footwear, jewelry, religious attributes of a PL; (i) infor- 
mation on PLs doing physical exercise and sports; (j) information about PLs' "hobbies", in some cases they ensure more "positive" perception of the PLs' images.(k) In case of PL AFCs' personal contacts with the Russian citizens the "manner of handshake" matters.

The perception of the PL AFCs' images is determined not only by the volume/content of the information received by the RCs on items "a"-"f". It is also determined by their approaches to evaluation of this information, which depend on PLs' social and economic group, political party (sociopolitical movement); age, gender, health condition and other factors.

\section{FORMATION OF THE FOREIGN PLS' IMAGES IN THE MINDS OF RUSSIAN CITIZENS: THE ANALYSIS OF PURPOSES, METHODS AND MAJOR CONTRIBUTORS}

Generally, the images of the PL AFCs in the minds of RCs are formed on the basis of a set of "types" of information: content neutral (for example, factual), positive, negative. The latter two types may have different degrees of manifestation; be explicit or veiled; be combined with each other in separate materials and/or with neutral information.

Various categories of legal entities and individual persons (both Russian and foreign) may participate in the creation, dissemination (promotion) and accessibility of information about the PL AFCs, including PL AFCs themselves; specialists in political science; legislative and executive authorities; political parties and social and political movements; politicians; different categories of journalists, commentators; IT specialists, etc. As a special category in the context of the development of ITCT, individual persons and their groups (including informal groups, societies, movements, etc.), whose activities are specifically aimed at destabilizing the social and economic situation, provoking ethnic and/or interfaith conflicts; the complication of international relations - in a single country, a group of countries or even at the world level should be considered.

These categories of people may have independent, overlapping and opposing objectives; their actions in time and direction are not usually agreed upon. At the same time, informational activity in solving the tasks of managing the PL AFCs' images usually increases during the period of election campaigns; in the occurrence of state or governmental crises; complications of the social and economic situation, etc.

Below, the issues of image management (Markelov, 2015; Sineokaya, 2017; Tskrialashvili, 2018; Svitich, 2019) of the PL AFCs from the positions of various categories of persons are consequently discussed. 
(1) Typically, the PLs of foreign countries themselves and/or their image makers set the following goals: to create (or manage) personal "positive" images of politicians in the minds of the RCs; ensure the confidence of the political and economic elite of Russia and RCs in the decisions and actions of these PLs; support the development of their countries' international ties with Russia, with Russian politicians, business structures; to combat the spread of negative information about the PLs, including fake one (Zakharova, 2018). In the minds of RCs, the images of foreign PLs can also be associated with the countries they represent (based on television broadcasts, photographs, IP impressions of tourist trips to these countries, personal contacts with these countries' citizens); with processes in the implementation of which the PLs directly participate, etc.

Specific actions within the framework of image management (Markelov, 2015; Sineokaya, 2017; Tskrialashvili, 2018; Dmitrieva, 2018): active spread of "positive information" about them in Ru-part of the Internet, traditional Russian-language media - including direct participation of embassies and consulates of the respective countries in Russia, their cultural centers; posting the "positive information" about PL AFCs in Russian on the Internet, their images that arouse sympathy; identification of fake (Zakharova, 2018) and tendentious information, combating it. However, direct refutations of false information by the PL AFCs themselves are usually ineffective. They can be made by PLs' spokespersons, other politicians, journalists, etc.

The following categories of legal entities and individual persons may take part in the formation and dissemination of negative information about PL AFCs, inter alia in the Russian language: foreign and domestic political opponents of PLs' economic, national, demographic, informational, religious and other types of policies; competitors for political leadership. Political technologists are usually used to generate, accumulate and disseminate negative information about PL AFCs; modern ITCT, television, traditional print media are used less.

Negative information about PLs may include the following: (a) specially selected true negative information about the PLs themselves and/or their activities; (b) tendentious assessments of PLAFCs activities by various IP, parties, organizations, etc., including "extracted" from the contexts in random; (c) fake (fictional) information about PL AFCs, as well as comments on their actions by other politicians, specialists, etc.; (d) usage of associated images of PL AFCs with negative phenomena/processes; with other PLs(including deceased) with a malevolent reputation. (e) Negative information about friends and closest relatives of PLs; (f) caricatures of the 
PLsf1) Figures (Svitich, 2019) - made manually and on the PC, including using "graphic tablets," for example, by Wacom. f2) Real PLs' photos edited with the help of computer programs with distortions specifically aimed to form negative perception of IP;(g) image edition, including PLs' photo with replacement of "environment;" (h) memes - they emphasize some features of the IP; (i) documentary (or claimed documentary) audio/video recordings of PL AFCs - regarding the formation of their images they may be positive, neutral or negative. It depends on the selection of video fragments; their sequences; narrator text; inscriptions, etc.; (j) in "humorous videos" about the PLAFCs, their images (including in combinations with their relatives, other politicians, animals, natural objects, etc.) can be presented as "friendly-humorous"; grotesque, sometimes extremely negative; (k) role-playing games can also use "PL characters." Through this "means" images of PLAFCs can be introduced to the youth.

As a result of the development of ITCT, the production of caricatures, memes, videos about PL AFCs has become available to a wide range of people with minimal ITCT competence; (Brumshteyn \& Kuzmina, 2014) edited images often look very realistic; videos often use "computersynthesized phrases" that the PLs themselves did not use (while preserving the main features of the speech of politicians, their diction, etc.). Therefore, distinguishing between real and "distorted" images or videos is often quite difficult.

Of particular importance for PLs is the creation (preservation) of positive images in foreign countries (including not from the G20), in which a significant part of the population is Russian-speaking; have relatives in Russia; travel to Russia to work or study; have business interests in Russia; participate in joint research, development, etc. In addition, some AFCs open "polling stations" for its citizens in Russia during elections. Their opinion on the PLs of their countries is formed by the information influenced by the Russian media, employers, RCs, etc.

(2) The goals of the highest body of executive power of Russia in relation to the images of PL AFCs are to provide RCs' support for decisions and actions made regarding these politicians, sometimes their countries. Possible options for such actions are the following: (a) public comments on PLAFCs' actions which can be made by the heads of these bodies, their press secretaries, etc.; (b) public statements to PLAFCs; (c) summoning the ambassadors of the respective countries to the Russian Ministry of Foreign Affairs to express "discontent" with the actions of the PL AFCs, their statements, etc.; (d) personal meetings of Russian politicians with the PL AFCs, other forms of contacts - including remote ones; (e) preparation and implementation of PLs' visits to Russia, return visits of Russian politicians 
to these countries, insurance of adequate coverage of such visits in the media, Internet, etc.; (f) preparation and conduct of bilateral or multilateral negotiations involving PL AFCs; (g) carrying out shared press conferences with PL AFCs by Russian politicians - in Russia and abroad; (h) formation and implementation of official international treaties/agreements with countries represented by PLAFCs; (i) broader connections with the PL AFCs' countries in various areas, including infosphere; $(\mathbf{j})$ creation of favorable conditions for the activities of embassies, consulates, cultural centers of AFCs in Russia - including infosphere; (k) usage of "protective" (restrictive) actions with respect to specific PL AFCs, countries they represent, organizations, etc. To ensure RCs' support for such actions, their negative (or partially negative) perception of PLs' images is necessary; understanding that the actions of these PLs impair Russian interests, organizations, citizens, etc.

(3) For the highest bodies of the legislative power of Russia, the images of PL AFCs in the minds of the RCs are important for solving such problems as the following: (a) Russian international ties development, including such at the "inter-parliamentary level;" (b) preparation and conduction of PLAFCs' visits to Russia - especially if their contacts with the legislative authorities are planned; (c) participation in the preparation of international treaties and agreements with separate countries; their associations; with international organizations, etc.

(4) For the media of the national wide level and for Internet portals; the images of PL AFCs are important with regard to the news and, especially, analytical information creation: about these politicians personally, about the countries they represent, about the social and political processes in these countries. At the same time, the "tonality" of the content of the materials is important, including direct assessments of the PLs' activities; the composition of words and expressions used, which can bear an emotional color. Algorithms used for automated evaluation of text tonality (Markelov, Brumshteyn \& Golovin, 2018) are based on expert categorization of the used vocabulary as "positive" or "negative"; definition of amount of words and expressions of these categories in materials about PLs.

(5) The images of PL AFCs in the RCs minds are important for Russian political parties and social movements for making decisions on statements regarding PLs' actions; on the appropriateness of meetings of the leaders of these parties with the PLAFCs, etc. Attitude of Russian parties to PL AFCs may vary significantly. It can change with shifts in foreign and domestic political situation. 
(6) For Russian regional executive and legislative authorities, images of foreign PLs of various "hierarchical" levels, including leading politicians of border parts of countries that are not part of the G20, may be important.

(7) In Russian regional media (especially in "national languages"), the tonality (Markelov, Brumshteyn \& Golovin, 2018) of PLs' reports from foreign countries may differ slightly compared to nation wide ones. The reasons are higher (compared to the average in Russia) share of people of the same nationality as in foreign countries represented by the politicians in the region; larger number of "guest workers" from these countries in the regions; same religion of foreign PLs and of a significant part of the population of Russian regions ,etc.

\section{ANALYSIS OF THE MAIN FACTORS AFFECTING THE IMAGES OF POLITICAL LEADERS OF FOREIGN COUNTRIES' PERCEPTION BY RCS}

Such factors are the following: (a) the opinion about the politicians already held by separate RCs; (b) the amount of new actual information received by Russian citizens about these politicians on the goals, features and results of their activities; (c) the volume of potentially accessible information about PL AFCs for the RCs, including usage of the Internet "search engines", machine translators, etc.; (d) "tonality" of the information about PL AFCs coming to the RCs; (e) available resources of citizens' clock face; (f) the degree of "competitive tension" between different means of information for separate RCs.

Features of image formation conditions of PL AFCs of Russian citizens are high level of informational competition between different means of information about them to the RCs; considerable redundancy of information on these politicians in info sphere; multiple informational repetitions about the politicians in different sources, sometimes with different tonality; wide use of methods of "political advertising", political image management and so forth, including World Wide Web; the data intended for discreditation of politicians and/or their groups' existence in infosphere.

Under such circumstances an important role is played by ITCT enhancement, including the following; (1) improvement of hardware: PC, servers, laptops, smartphones, etc.; (2) improvement of software functionality, including "intellectuality" of search engines of the Internet, information repositories; (3) higher speed of access to information and traffic volumes in telecommunication networks, reliability of communication channels improvement; (4) general increase in volumes of information in the Internet resources, on social networks, on personal and office PCs and 
other devices. Consequences of these processes are: (a) general increase in "information load" on Internet resources users, including learning information, selecting materials, etc.; (b) growth in volumes of information, potentially available to them, including the information about PL AFCs; (c) increase in "the informational competition" between various means of information - including in news feeds on the Internet portals, in media and so forth; (d) increase in efficiency of submission of electronic news information, including the information, connected with activity of PL AFCs, with these countries themselves; (e) improvement of availability of information on PL AFCs first of all due to improvement of intellectuality of search engines of the Internet; (f) providing the users with opportunities of management of character and volumes of the efficient information through various channels about PL AFCs' activities. At the same time a certain ITCT-competence of citizens is required for the "e" and " $f$ " items; (Brumshteyn \& Kuzmina, 2014) (g) low level of RCs' confidence in the information on large number of websites, including due to existence of the numerous "incorrectly worded" headlines.

The images of the PLs of most (but not all!) politicians from foreign countries in the RCs' public mind are usually formed with less information than of Russian politicians. The reasons are less Russian-language news about foreign PLs - except for special situations, usually short in time; RCs' "linguistic barriers" with information on foreign PL in English and especially in other languages. At the same time, machine translators make it possible to grasp the general content of the texts only, not with the details.

\section{CONCLUSIONS}

1. The development of ITCT has significantly changed the conditions for politicians. It forced them to pay much more attention to the formation of their images in the public minds of their own and foreign countries' citizens.

2. The perception of PLs images by individuals is based on a number of "components". At the same time, for most Russian citizens, the key factors are PLs' gender, appearance, manner of behavior, speech.

3. Actions related to the management of PLs' images in the minds of Russian citizens are carried out by various categories of legal entities and individual persons, which can pursue both common and separate goals. In some cases, these actions are of direct "confrontation" in infosphere, they may include usage of fake information. 
4. The significant redundancy of the infosphere makes it difficult to "target promote" information about foreign politicians to RCs within the framework of image management.

\section{References}

Brumstein, Y. M., \& Kuzmina, A. B. (2014). ICT competence of countries, regions, organizations and individuals: A Systemic Analysis of Goals, Directions, and Assessment Methods. Caspian Journal: Management and High Technology, (2 (26)), 47-63. (In Russian).

Dmitrieva, M. A. (2018). Information Manipulation Technologies in the Context of the Shaping of the Politician's Image. Current Issues in Science, (41), 138-140. (In Russian).

Karimova, N. I. (2012). The Internet as an information and communication tool for constructing a politician's image. Economics and Management: Scientific and Practical Journal, (2), 114-116. (In Russian).

Kurkemova, E. S. (2018). Strategies of forming and broadcasting the image of politicians on the Internet. In Astrapolis: Astrakhan Political Studies (pp. 130-134). Astrakhan: Individual Entrepreneur Roman Sorokin. (In Russian).

Markelov, K. A. (2015). Economic Security: Geopolitical and Regional Aspects. Economics and management: problems, solutions, 3(12), 6-11. (In Russian).

Markelov, K. A., Brumstein, Y. M., \& Golovin, V. G. (2018). Integration Processes of the Caspian Sea States and their Littoral Territories: A Systemic Analysis of the Sources and Structure of Information. Bulletin of Eurasian Science, 10(5), 34. (In Russian).

Saprykina, M. F. (2018). Non-verbal components of a politician's image in TV stories. In Student and Science (Humanities cycle)-2018. Materials of the international student scientific-practical conference. 2018 (pp. 457-461). Magnitogorsk: Magnitogorsk State Technical University named after G.I. Nosov. G.I. Nosov. (In Russian).

Sineokaya, N. A. (2017). The image of the politician in the modern electronic media (the example of female politicians in Germany). In Philology and Education. Scientific, pedagogical, and local history heritage of N.M. Lebedev. Conference materials. (pp. 235-242). Tver: SfK-Office LLC. (In Russian).

Svitich, A. L. (2019). Visualization of the image of a political figure in graphic illustration (Russian and foreign experience of the print media). Mediaallmanac, (4), 30-44. doi: 10.30547/mediaalmanah.4.2019.3044 (In Russian).

Tskrialashvili, A. D. (2018). Online Image: Social Networking Profile as the Face of a Politician. Nauka.me, (2), 6. (In Russian).

Vasilyeva, V. N., \& Zhigunova, G. V. (Eds.). (2016). Politician's Image: Problems of Formation, Promotion and Research. Murmansk: Murmansk Arctic State University. (In Russian). 
Veretelnikova, V. A. (2016). Peculiarities of the formation of the image of political leaders of Russia, the United States and Germany in the Russian and foreign media. In Cyril and Methodius Readings in SAMSTU. Proceedings of the XII All-Russian (with international participation) scientific conference of students, undergraduates and graduate students. Samara State Technical University. 2016 (pp. 240-243). Samara: Samara State Technical University. (In Russian).

Zakharova, M. V. (2018). Fake Information and Politician's Image: Effects, Models of Counteraction (French Experience). The Age of Information, 2(2), 98-99. (In Russian).

\section{Список литературы}

Брумштейн, Ю. М., \& Кузьмина, А. Б. (2014). ИКТ-компетентность стран, регионов, организаций и физических лиц: Системный анализ целей, направлений и методов оценки. Прикаспийский журнал: управление и высокие технологии, (2 (26)), 47-63.

Васильева, В. Н., \& Жигунова, Г. В. (Ред.). (2016). Имидж политика: Проблемы формирования, продвижения и исследования. Мурманск: Мурманский арктический государственный университет.

Веретельникова, В. А. (2016). Особенности формирования образа политических лидеров России, США и Германии в российских и зарубежных СМИ. В Кирилло-Мефодиевские чтения в САМГТУ. Сборник материалов ХІІ Всероссийской (с международным участием) научной конференции студентов, магистрантов и аспирантов. Самарский государственный технический университет. 2016 (сс. 240-243). Самара: Самарский государственный технический университет.

Дмитриева, М. А. (2018). Технологии Манипулирования Информацией В Контексте Формирования Имиджа Политика. Актуальные Вопросы Науки, (41), 138-140.

Захарова, М. В. (2018). Фейковая информация и имидж политика: Эффекты, модели противодействия (опыт Франции). Век Информащии, 2(2), 98-99.

Каримова, Н. И. (2012). Интернет как информационно-коммуникационный инструмент конструирования имиджа политика. Экономика и управление: научно-практический журнал, (2), 114-116.

Куркемова, Э. С. (2018). Стратегии формирования и трансляции имиджа политиков в сети Интернет. В Астраполис: Астраханские политические исследования (сс. 130-134). Астрахань: Индивидуальный предприниматель Сорокин Роман Васильевич.

Маркелов, К. А. (2015). Экономическая безопасность: Геополитические и региональные аспекты. Экономика и управление: проблемы, решения, 3(12), 611.

Маркелов, Константин Алексеевич, Брумштейн, Ю. М., \& Головин, В. Г. (2018). Процессы интеграции прикаспийских государств и их приморских терри- 
торий: Системный анализ источников и структуры информации. Вестник евразийской науки, 10(5), 34.

Сапрыкина, М. Ф. (2018). Невербальные составляющие имиджа политика в телевизионных сюжетах. В Студент и наука (гуманитарный цикл)-2018. Материаль международной студенческой научно-практической конференuии. 2018 (сс. 457-461). Магнитогорск: Магнитогорский государственный технический университет им. Г.И. Носова.

Свитич, А. Л. (2019). Визуализация образа политического деятеля в графической иллюстрации (российский и зарубежный опыт печатных СМИ). Медиаальманах, (4), 30-44. doi: 10.30547/mediaalmanah.4.2019.3044

Синеокая, Н. А. (2017). Имидж политика, формируемый в современных электронных СМИ (на примере женщин-политиков Германии). В Филология и просветительство. Научное, педагогическое, краеведческое наследие Н. М. Лебедева. Материальи конференщии (сс. 235-242). Тверь: ООО «СФКофис».

Цкриалашвили, А. Д. (2018). Имидж в Интернете: Профиль в социальной сети как лицо политика. Nauka.me, (2), 6. 